\title{
Opini Pemilih Pemula Surabaya Terhadap Iklan Politik Para Kandidat di Pilkada
}

\author{
Agusly Irawan Aritonang, S.Sos.,M.A \\ Universitas Kristen Petra Surabaya \\ Jalan Siwalankerto No. 121-131 Surabaya 60236 \\ *e-mail : agusly_irawan@yahoo.com
}

\begin{abstract}
Election Campaign Period is a period in political events where candidates have the opportunity to introduce themselves to the public. Through various forms and channels of communication, candidates endeavor to convey their ideas and profile. One form of communication channel is political advertising. The target group that is always interesting to be targeted by advertisements is the beginner voter group. With a very significant number of them (19\% of the total DPT city of Surabaya), the beginner voter is a potential "market" to work on so that a candidate's campaign message can be conveyed. This study wants to see how the opinions of the beginner voters, especially in the city of Surabaya about the ads of candidates for Cagub Cawagub in the East Java Regional Election 2018. Using a quantitative approach with survey methods, the results show that both candidate pairs' ads, namely Khofifah-Emil and Gus Ipul- Puti are positively opinion by beginner voters. However, when viewed from each opinion component, namely Trust, Values, and Expectations, the Gus Ipul-Puti advertisement has a higher component in Values and Expectations while the Khofifah advertisement pair is high in the Trust component.
\end{abstract}

Keywords: opinion, beginner voter, Jatim Election

\begin{abstract}
ABSTRAK
Masa Kampanye Pilkada merupakan sebuah periode dalam event politik dimana para kandidat berkesempatan untuk memperkenalkan dirinya kepada publik. Melalui ragam bentuk dan saluran komunikasi, para kandidat berupaya menyampaikan gagasan dan profil dirinya. Salah satu bentuk bentuk saluran komunikasi itu adalah iklan politik. Kelompok sasaran yang selalu menarik untuk dijadikan sasaran iklan adalah kelompok pemilih pemula. Dengan jumlah yang sangat signifikan jumlahnya (19\% dari total DPT Kota Surabaya) maka pemilih pemula merupakan "pasar" potensial untuk digarap agar pesan kampanye seorang kandidat bisa tersampaikan. Penelitian ini ingin melihat bagaimana opini para pemilih pemula khususnya di Kota Surabaya tentang iklan para kandidat Cagub Cawagub dalam PIlkada Jatim 2018. Menggunakan pendekatan kuantitatif dengan metode survey didapatkan hasil bahwa kedua iklan pasangan kandidat yaitu pasangan Khofifah- Emil dan Gus Ipul- Puti diopinikan positif oleh pemilih pemula. Namun jika dilihat dari masing masing kompenen opini yaitu Kepercayaan, Nilai, dan Harapan maka untuk iklan pasangan Gus Ipul-Puti memiliki komponen yang lebih tinggi di Nilai dan Harapan sedangkan iklan pasangan Khofifah tinggi di komponen Kepercayaan.
\end{abstract}

Kata kunci: Opini, Pemilih Pemula, Pilkada Jatim 


\section{Latar Belakang}

Jawa Timur mengadakan pemilihan kepala daerah Gubernur dan Wakil Gubernur 2018. Sebagai sebuah agenda politik, hal ini tentu merupakan pesta demokrasi bagi masyarakat Jawa Timur untuk menentukan pemimpinnya 5 tahun kedepan. Tentu harapannya agar terpilh pemimpin yang bisa membawa kebaikan bagi wilayah Jawa Timur. Diawali gerakan gerakan maupun komunikasi politik oleh bakal calon (balon) baik dengan partai politik maupun organisasi lainnya maka resmi sudah 2 pasangan calon yang mendaftar ke KPU Provinsi Jawa Timur. Pasangan tersebut yaitu pasangan Khofifah Indar Parawansa - Emil Dardak dan Saifullah Yusuf (Gus Ipul) dan Puti Guntur Soekarnoputri. Pasangan Khofifah Indar Parawansa Emil Dardak didukung oleh koalisi partai Demokrat (13 kursi DPRD), Golkar (11 kursi), PPP (5 kursi), Hanura (2 kursi), PAN ( 7 kursi) dengan total 42 kursi. Sedangkan Pasangan Saifullah Yusuf-Puti Guntur Soekarno didukung oleh 4 koalisi partai yaitu PKB (20 kursi DPRD), PDIP (19 kursi), PKS (6 kursi), Gerindra (13 kursi) dengan total 58 kursi.(http://nasional.kompas.com/read/ 2018/01/11/19120451/fakta-seputarpilkada-jawa-timur)

Secara umum berdasarkan rangkaian kegiatan yang sudah ditetapkan, pemilihan kepala daerah Jatim 2018 terdiri dari: pendaftaran bakal calon pada tanggal 8-10 Januari 2018, penetapan calon tanggal 12 Februari 2018, kegiatan kampanye mulai 15 Februari 2018 hingga 23 Juni 2018, diikuti masa tenang pada tanggal 24-26 juni hingga pemungutan suara pada tanggal 27 juni 2018 serta rekapitulasi sekaligus penetapan hasil pungutan suara yang bakal menentukan siapa yang akan terpilih memimpin Jawa Timur untuk 5 tahun kedepan. Dari sekian tahapan tersebut, salah satu tahapan yang penting dari kacamata marketing politik tentu saja tahapan kampanye. Hal ini dikarenakan tahapan ini merupakan kesempatan bagi para kandidat nantinya untuk memperkenalkan dirinya, visi misinya, program programnya dengan harapan bisa menarik minat para pemilik suara. Intinya tahapan kampanye merupakan periode yang bisa digunakan untuk menjual kandidat dengan seluruh kelebihan kelebihannya. Pada kenyataannya masa kampanye pada periode pilkada Jatim 2018 ini cukup panjang sekitar 5 bulan. Yang artinya pasangan kandidat punya waktu yang cukup untuk "memasarkan" dirinya.

Salah satu metode kandidat untuk berkampanye antara lain dengan menampilkan iklan iklan politik. Tentu saja iklan ini bisa bermacam macam baik di media massa, media sosial maupun iklan luar ruang. Dan iklan politik masih menjadi sarana yang menjanjikan untuk memperkenalkan calon dan program programnya. Jika dipahami sebagai sebuah proses komunikasi, iklan dengan kandungan pesan pesan politik tertentu disampaikan kepada audiens sehingga audiens bisa mencermati dan lebih jauh lagi menerima pesan sehingga diyakini berdampak terhadap diri audiens dalam hal ini para pemilik suara.

Salah satu kelompok pemilik suara yang potensial dijadikan sasaran untuk berkampanye adalah para pemilih pemula. Para pemilih pemula sebagai kaum muda yang baru pertama kali akan memberikan hak suaranya dalam pemilihan gubernur dan wakil gubernur Jawa Timur ini tentu menjadi sasaran empuk untuk terus digempur pesan pesan politik sehingga mereka bisa mengetahui, memiliki sikap dan akhirnya bisa melakukan tindakan memilih atau 
tidak kandidat kandidat tertentu. Dalam konteks pilkada Jatim 2018, data menunjukkan jumlah pemilih pemula ada di angka 381.272 (data dari KPU Kota Surabaya). Sedangkan angka pemilih sendiri berdasarkan DPT Kota Surabaya tercatat 2.006.661 pemilih. Sehingga jika dikalkulasikan terdapat $19 \%$ pemilih pemula di Kota Surabaya untuk pilkada JAtim 2018 ini. Sungguh angka yang signifikan sebagai potensi suara. Selain itu keterlibatan kaum muda maupun pemilih pemula untuk aktif memberikan hak suara dalam pemilihan merupakan satu bentuk proses pendidikan politik yang baik bagi warga negara sehingga kaum muda diharapkan tidak apatis terhadap persoalan persoalan sosial maupun politik.

Salah satu bentuk aspirasi para pemilik suara baik pemula maupun non pemula adalah beropini. Sebagai ekspresi dari sebuah sikap maka opini khususnya publik menjadi penting untuk diketahui termasuk dalam konteks praktek komunikasi politik dalam kepentingan pemilihan kepala daerah. Sebagai contoh bagaimana opini publik terkait tingkat kepuasan petahana, tingkat kepercayaan publik terkait para pasangan kandidat maupun pada isu isu tertentu atau bahkan bagaimana pilihan publik terhadap para pasangan kandidat yang berkompetisi.

Terkait hal tersebut maka menjadi menarik dan penting untuk melihat bagaimana opini para pemilih pemula dalam mencermati iklan politik para kandidat yang nantinya akan bertarung dalam pilkada Jatim 2018. Sebagai sebuah metode berkomunikasi dan memperkenalkan diri pasangan kandidat kepada para pemilih maka iklan politik diyakini akan banyak bertebaran mulai dari media cetak, media elektronik, media sosial bahkan media luar ruang sekalipun.
Sehingga menjadi menarik pula untuk mengetahui bagaimana opini para pemilih pemula terkait iklan politik para pasangan kandidat Gubernur dan Wakil Gubernur Jawa Tumur 2018. Iklan Politik yang diteliti merupakan iklan audio visual yang ditayangkan di media sosial baik youtube maupun facebook.

Media sosial sebagai salah satu saluran komunikasi juga dipakai oleh para kandidat untuk berkampanye. Hal ini tentu sangat beralasan mengingat generasi yang merupakan pemilih pemula di pilkada ini merupakan generasi Z yang diyakini sangat dekat dan familiar dengan media sosial atau new media dibandingkan dengan media konvensional seperti media cetak, radio atau bahkan televisi. Maka menjadi sangat masuk akal iklan iklan politik para kandidat khususnya dalam konteks pilkada Jawa Timur ini juga bermunculan dan bisa diakes melalui media sosial seperti youtube dan facebook. Disamping itu pasangan kandidat Gus Ipul - Puti maupun Khofifah-Emil juga mengguankan saluran media Facebook sebagai media untuk berkampanye. Dan tentu saja gaya komunikasi melalui iklan politik kedua pasangan diyakini menyesuaikan dengan sasaran audiens anak muda sebagai target kampanye. Bila dicermati setidaknya ada beberapa iklan yang muncul baik di youtube maupun di akun facebook milik pasangan Gus Ipul Puti maupun Khofifah - Emil. Untuk pasangan Gus Ipul ada iklan politik "Pemuda Milenial jaman Now Ngomong Persatuan", "Pilih Pemimpin itu yang ada $\mathrm{N}$ nya" versi Cak Lontong, selain iklan Politik versi "Dilan". Sedangkan iklan politik Khofifah-Emil setidaknya ada iklan seperti "Nawa Bhakti Satya", Iklan Versi Rhoma Irama, disamping beberapa jenis 
iklan yang berisikan kegiatan Khofifah dan Emil.

Sasaran pemilih pemula yang akan dipilih adalah pemilih pemula yang berada di Surabaya. Tentu pemilihan Surabaya disertai dengan beberapa alasan antara lain Surabaya merupakan ibu kota propinsi sekaligus pusat pemerintahan Jawa Timur itu sendiri. Disamping sebagai ibu kota propinsi diyakini akses dan penetrasi akan informasi maupun media jauh lebih besar. Selain itu dilihat dari jumlah penduduk maka jumlah penduduk kota Surabaya terbesar dibandingkan Kabupaten dan Kota lainnya dengan angka 2.862.406 (data BPS Jawa Timur per 2016) maupun proyeksi BPS terkait jumlah penduduk di Surabaya pada tahun 2018 yaitu 2.885.555 yang juga lebih tinggi dibandingkan Kabupaten/ Kota lainnya di Jawa Timur. Selain itu jumlah pemilih di Kota Surabaya (berdasarkan DPT KPU Provinsi Jawa Timur tahun 2018) berjumlah 2.006.061 yang merupakan jumlah terbesar bila dibandingkan dengan jumlah pemilih di Kabupaten Kota lainnya di Jawa Timur.

Ada beberapa riset terdahulu terkait opini pemilih pemula terhadap iklan politik. Belinda Ochtiva (2017) yang melihat opini pemilih pemula Surabaya terhadap iklan mars perindo. Riset ini melihat bagaimana respon opini pemilih pemula terhadap iklan partai perindo. Iklan yang diputar adalah iklan partai politik di stasiun televisi. Hasilnya sebagian besar pemilih pemula memberikan opini positif terhadap iklan mars perindo tersebut. Riset lainnya adalah milik Abdul Jalil Akbar (2011) yang melihat opini pemilih pemula terhadap iklan para kandidat di Walikota Makassar 2008. Riset ini dilakukan dalam konteks pilkada namun lebih spesifik terhadap iklan di media massa khususnya surat kabar. Sedangkan riset oleh Ervina Sulistyo (2014) lebih melihat opini pemilih pemula terhadap iklan politik di televise dalam format kuis di salah satu stasiun televise. Dari ketiga riset terdahulu ini terdapat perbedaan dengan riset ini yaitu riset ini akan lebih berfokus melihat iklan politik para kandidat bukan partai kemudian format iklan adalah iklan audio visual yang tayang di media sosial khususnya youtube sebagai iklan yang resmi dari pasangan kandidat CAgub dan cawagub Pilkada Jatim 2018.

\section{Iklan Politik}

Iklan dapat dipahami sebagai segala bentuk penyajian nonpersonal dari promosi ide, barang atau jasa sebuah perusahaan tertentu yang disajikan di media massa cetak maupun media massa elektronik. Sehingga secara sederhana iklan sendiri bertujuan menjual sebuah produk. (Suparno dalam Heryanto 2013: 39). Iklan sendiri dapat dibagi menjadi iklan komersial, iklan layanan masyarakat, dan iklan politik.Sedangkan Dan Nimmo sendiri membagi iklan menjadi 2 jenis yaitu iklan komersial dan non komersial. Iklan komersial meliputi periklanan konsumen (untuk menjual produk atau jasa) dan periklanan perusahaan sedangkan iklan non komersial yaitu iklan yang dilakukan oleh kelompok amal, pemerintah, kelompok politik (partai politik, golongan yang berpengaruh,dsb) dan para kandidat politik. (Nimmo, 1989: 149).

Iklan politik dipahami sebagai proses komunikasi dimana seorang sumber (biasanya calon politik atau partai) membeli kesempatan untuk mengekspos penerima pada pesan politik melalui saluran massa dengan efek yang diinginkan yaitu mempengaruhi sikap, keyakinan, dan/atau perilaku politik mereka. (Kaid,1981:250).

Robert Baukus dalam Combs (1993) menyampaikan iklan politik dapat dibedakan menjadi beberapa yaitu : 
1. Iklan serangan, yang ditujukan untuk mengdiskreditkan lawan.

2. Iklan argumen, yang memperlihatkan kemampuan para kandidat untuk mengatasi masalah-masalah yang mereka hadapi.

3. Iklan ID, yang memberi pemahaman mengenai siapa sang kandidat kepada pemilih.

4. Iklan resolusi, di mana para kandidat menyimpulkan pemikiran mereka untuk para pemilih. ( Cangara, 2011: 281)

Kotler juga menyampaikan unsur pesan terkait iklan. Kotler (2003:569-573) menyebutkan unsur pesan iklan antara lain:

1.isi pesan

Isi pesan merujuk pada apa yang dikatakan di dalam iklan pada audiens agar mendapat respons yang diinginkan. Dalam menyusun sebuah iklan yang baik, perusahaan harus dapat mengemas pesan yang ingin disampaikan semenarik mungkin. Berikut jenis daya tarik isi pesan iklan tersebut :

a. Rasional

Isi pesan mengandung nilai mutu, nilai ekonomis, manfaat, dan kinerja sebuah produk sehingga audiens memiliki pengetahuan dan mengenal produk, serta dapat memilih produk atas dasar pilihan mereka sendiri.

\section{b. Emosional}

Isi pesan iklan dapat membangkitkan emosi positif ataupun negatif yang kemudian akan memotivasi adanya respon.

c. Moral

Isi pesan ini mengarahkan audiens pada apa yang baik/benar. Isi pesan juga mendorong audiens untuk mendukung terciptanya moral di masyarakat . Isi pesan dalam iklan yang bersifat informatif harus memenuhi kriteria yaitu mudah dipahami dan mudah diingat oleh audiens.

\section{Struktur pesan}

Struktur pesan iklan yang baik dapat dimengerti secara tersurat maupun tersirat. Tersurat berarti pesan iklan tersebut dapat menyampaikan kesimpulan yang sudah jelas maksudnya sedangkan tersirat berarti iklan tersebut dapat menampilkan kesimpulan yang tidak terlihat jelas maksudnya. Terdapat lima hal yang harus diperhatikan dalam menyusun sebuah struktur pesan yang baik : (Nuryana, 2013: 165)

\section{a. Attention (perhatian)}

Penyusunan pesan dimulai dengan upaya untuk menarik perhatian audiens.

b. Needs (kebutuhan)

Pesan iklan dikemas sedemikian rupa agar audiens merasa pesan tersebut mampu menjawab kebutuhannya akan informasi.

c. Satisfaction (kepuasan)

Pada tahap ini komunikator berusaha membuat audiens menyetujui gagasan yang mereka ajukan dalam pesan iklan.

d. Visualization (visualisasi)

Dalam tahap ini komunikator memproyeksikan gagasan dalam pesan iklan dan pengaruhnya terhadap audiens.

e. Action (tindakan)

Pada akhirnya pesan iklan merangkum tahapan penyampaian pesan iklan tersebut dalam sebuah tindakan nyata dengan harapan audiens ikut melakukan tindakan tersebut.

\section{Format pesan}

Format pesan iklan merupakan bentuk menyampaikan iklan tersebut kepada audiens secara simbolis . Pesan iklan yang disampaikan lewat media televisi wajib memperhatikan elemen elemen yang bersifat visual dan audio secara sekaligus yang terdiri dari :

a. Judul/tagline

Judul/tagline merupakan serangkaian kalimat atau kata kata pendek. Sekarang ini tagline seringkali berupa pernyataan yang 
terdiri dari satu atau dua kalimat dan ditampilkan secara mencolok untuk menarik perhatian.

b. Kata kata

Pemilihan kata kata yang ditampilkan dalam iklan harus dapat dirumuskan maksud dan tujuannya.

c. Warna

Warna dalam iklan menampilkan suasana yang dikehendaki secara keseluruhan.

d. Video

Video pada umumnya mendominasi iklan dengan sungguhan kumpulan adegan demi adegan yang saling mendukung sehingga video harus dapat menarik perhatian dan mengkomunikasikan gagasan atau pesan kunci pada iklan.

e. Audio

Audio adalah elemen suara, musik, ataupun efek suara pada iklan. Audio penting untuk diperhatikan karen elemen audio melengkapi dan menegaskan pesan yang tampak dari video.

\section{Sumber pesan}

Pesan iklan yang disampaikan oleh sumber yang menarik, terkenal ataupun, terpercaya, akan memudahkan pesan iklan. Faktor faktor yang mempengaruhi kualitas sumber pesan iklan :

a. Expertise (keahlian)

Keahlian merupakan sebuah pengetahuan dan kemampuan khusus yang dimiliki sumber pesan yang dapat mendukung pesan yang disampaikan.

b. Trussworthiness (terpercaya)

Sebuah sumber yang terpercaya menyampaikan pesan yang dianggap objektif dan jujur.

c. Likeability

Seorang sumber pesan harus memiliki kemampuan untuk disukai oleh audiensnya sehingga audiens tertarik untuk mengetahui pesan iklan tersebut.

\section{Pemilih Pemula}

Pemilih merupakan penduduk yang berusia paling rendah berusia 17 tahun atau sudah/pernah kawin yang terdaftar dalam pemilihan. Defenisi merupakan defenisi yang disampaikan dalam Peraturan KPU Republik Indonesia No 2 tahun 2017 tentang Pemutakhiran Data dan Penyusunan Daftar Pemilih Dalam Pemilihan Gubernur dan Wakil Gubernur, Bupati dan Wakil Bupati, Dan/Atau Walikota dan Wakil Walikota. Dalam konteks pemilihan di Indonesia, pemilih sendiri bisa dikategorikan menjadi 3 kategori yaitu :

1. Pemilih rasional, yaitu pemilih yang benar benar memilih partai berdasarkan penilaian dan analisis mendalam.

2. Pemilih kritis emosional, yaitu pemilih yang masih idelais dan idak kenal kompromi.

3. Pemilih pemula, yakni pemilih yang baru pertama kali memilih karena usia mereka baru memasuki usia pemilih. Kelompok yang berentang usia 17-21 tahun ini adalah mereka yang berstatus pelajar, mahasiswa, serta pekerja muda. (Azwar, 2008)

Kampanye politik sendiri juga cenderung membagi pemilih menjadi 3 kategori pula. Kategori tersebut yaitu :

1. Basis pemilih yang memilih kandidat

2. Swing voters atau pemilih mengambang yaitu basis pemilih yang bisa dipersuasi oleh kandidat manapun dan

3. Basis pemilih yang memilih kandidat lawan yang tidak bisa dipersuasi dengan cara apapun. (Brooks dan Farmer, 2009).

Pemilih pemula, berdasarkan Peraturan KPU Republik Indonesia No 2 tahun 2017 tentang Pemutakhiran Data dan Penyusunan Daftar Pemilih Dalam Pemilihan Gubernur dan Wakil Gubernur, Bupati dan Wakil Bupati, Dan/Atau Walikota dan Wakil Walikota meliputi 
pemilih yang genap berumur 17 tahun atau lebih pada hari pemungutan suara atau pemilih yang telah berubah status dari status anggota Tentara Nasional Indonesia atau kepolisian Negara Republik Indonesia menjadi status sipil.

Opini merupakan tanggapan aktif terhadap rangsangan, tanggapan, yang disusun melalui interpretasi personal yang diturunkan dan turut membentuk citra. Setiap opini merefleksikan organisasi yang kompleks yang terdiri dari tiga komponen yaitu kepercayaan, nilai, dan pengharapan. (Nimmo,2010: 10). Terkait ketiga komponen tersebut dapat dijelaskan sebagai berikut :

a. Kepercayaan

Orang yang mempunyai kepercayaan mempersepsi hubungan antara dua hal atau antara sesuatu dengan karakteristiknya. Kepercayaan sangat dekat dengan asosiasinya dengan aspek kognitif atau pikiran dari citra dan interpretasi personal. Dan didalamnya terkandung kredulitas yaitu orang yang percaya atau tak percaya. Intensitas keredulitas bervariasi dari keyakinan yang tak tergoyahkan sampai sama sekali tak percaya. Akhirnya kepercayaan berbeda beda menurut tingkat kepentingannya bagi individu.

b. Nilai

Nilai merujuk pada preferensi yang dimiliki orang terhadap tujuan tertentu atau cara tertentu dalam melakukan sesuatu. (Rokeach, Milton dalam Nimmo, 2010: 13). Preferensi ini sendiri berasosiasi dengan isi afektif atua perasaan, citra personal yang membantu orang dalam menilai diri sendiri dan lingkungannya. Nilai itu sendiri bervariasi dalam beberapa hal : arah yaitu suka dan tak suka; intensitas dari sisi kuat, sedang, lemah; dan penting nilai tertentu bagi seseorang.

c. Pengharapan

Pengharapan berkaitan dengan aspek konatif, atau kecendrungan dari citra personal dan diproses secara interpretatif oleh para psikolog yang kadang kadang disamakan dengan gerak hati, hasrat, kemauan, dan dorongan. Pengharapan personal merupakan hal paling penting dalam politik. Orang sering mempertimbangkan peristiwa politik atau penampilan pemimpin berdasarkan apa yang diharapkannya akan terjadi. Jika pengharapan itu tinggi dan peristiwa atau perbuatan pemimpin tidak sesuai dengannya, orang kecewa atau meremhkan politikus. Bila pengharapan itu rendah dan dilampaui dengan mudah, orang bisa mendapat kejutan yang menyenangkan bahkan meskipun hasilnya jelek. (Nimmo, 2010: 15).

Opini publik bisa dipahami sebagai gabungan pendapat perseorangan mengenai suatu isu yang dapat memengaruhi orang lain, serta memungkinkan seseorang dapat memengaruhi pendapat pendapat tersebut. Ini berarti pendapat umum hanya bisa terbentuk kalau menjadi bahan pembicaraan umum, atau jika banyak orang penting (elite) mengemukakan pendapat mereka tentang suau isu sehingga bisa menimbulkan pro atau kontra di kalangan anggota masyarakat. " (Cangara, 2009: 158).

Berdasarkan latar belakang tersebut maka rumusan masalah yang ingin diteliti adalah : Bagaimana opini pemilih pemula Surabaya terhadap iklan politik para kandidat di pilkada Jawa Timur 2018?

\section{Metode}

\section{Jenis Penelitian}

Penelitian yang akan dilakukan ini merupakan penelitian dengan pendekatan kuantitatif dengan jenis penelitian deskripstif serta menggunakan metode survei dengan cara membagikan kuesioner secara langsung kepada responden.

\section{Populasi dan Sample}

\section{Populasi}

Populasi dalam penelitian ini adalah keseluruhan pemilih pemula yang terdaftar dalam 
DPT (Daftar Pemilih Tetap) Kota Surabaya. Berdasarkan rekapitulasi DPT oleh KPU kota Surabaya jumlah pemilih pemula di Kota Surabaya berjumlah 381.272 orang.

\section{Sampel}

Jumlah sampel dalam penelitian ini adalah

$$
\begin{aligned}
N= & \frac{N-}{2} \\
& =\frac{\mathrm{N} \cdot \mathrm{d}+1}{381 \cdot 272} \\
& =981 \cdot 272 \cdot(0,1) 2+1 \\
& =99,97 \text { (dibulatkan 100) }
\end{aligned}
$$

Adapun teknik penarikan sampel dilakukan dengan menggunakan metode non probability sampling yaitu sampling purposif dengan pertimbangan sebagai berikut :

1. Tidak diperolehnya secara rinci nama pemilih pemula yang terdaftar dalam Daftar Pemilih Tetap dari KPU Surabaya (merupakan informasi yang dikecualikan berdasarkan UU Keterbukaan Informasi Publik) yang akan dijadikan kerangka sampel.

2. Anggota populasi yang akan dijadikan sampel ini merupakan sampel yang sudah harus menonton kedua iklan kandidat pilkada Jatim yaitu Iklan Versi Dilan untuk Pasangan Gus Ipul - Puti dan Iklan versi Nawa Bhakti Satya untuk pasangan kandidat Khofifah- Emil secara full hingga iklan tersebut selesai.

\section{Pembahasan}

\section{Jenis Kelamin}

Terkait jenis kelamin responden, sebaran responden yang merupakan pemilih pemula dalam suvey opini kali ini bisa dilihat dari table di bawah ini.

Tabel 1 : jenis kelamin responden

\begin{tabular}{|l|l|c|}
\hline Jenis Kelamin & Jumlah & Persentase \\
\hline Laki Laki & 43 & $43 \%$ \\
\hline Perempuan & 57 & $57 \%$ \\
\hline Total & 100 & $100 \%$ \\
\hline
\end{tabular}

Sumber : Hasil Olahan Peneliti

\section{Usia Responden}

Terkait usia responden, sebaran responden yang merupakan pemilih pemula dalam suvey opini kali ini bisa dilihat dari table di bawah ini

Tabel 2 : usia responden

\begin{tabular}{|l|l|c|}
\hline Usia & Jumlah & Persentase \\
\hline 17 & 20 & $20 \%$ \\
\hline 18 & 19 & $19 \%$ \\
\hline 19 & 46 & $46 \%$ \\
\hline 20 & 10 & $10 \%$ \\
\hline 21 & 5 & $5 \%$ \\
\hline Total & 100 & $100 \%$ \\
\hline
\end{tabular}

Sumber : Hasil Olahan Peneliti

\section{Preferensi Politik}

Terkait pilihan responden, sebaran responden yang merupakan pemilih pemula dalam suvey opini kali ini bisa dilihat dari table di bawah ini

Tabel 3 : preferensi pilihan responden

\begin{tabular}{|l|l|c|}
\hline Preferensi Politik & Jumlah & Persentase \\
\hline Khofifah Emil & 28 & $28 \%$ \\
\hline Gus Ipul-Puti & 55 & $55 \%$ \\
\hline Golput & 17 & $17 \%$ \\
\hline Total & 100 & $100 \%$ \\
\hline
\end{tabular}

Sumber : Hasil Olahan Peneliti

\section{a.Komponen Kepercayaan Terhadap Iklan Gus Ipul - Puti}

Dalam komponen kepercayaan terhadap isi iklan politik Gus Ipul - Puti secara umum responden menunjukkan tingkat kepercayaan yang besar. Dalam kategori isi pesan responden menunjukkan kepercayaan paling tinggi pada item 9 yaitu iklan politik Gus Ipul Puti versi Milea menunjukkan sisi positif pasangan kandidat sebesar $61 \%$ berbanding $13 \%$ yang tidak setuju. Dilihat dari segi mean terbesar maka komponen kepercayaan terkait isi pesan mampu menumbuhkan sisi positif pasangan kandidat (item 9) memperoleh mean yang paling besar sebesar 3,62 berbanding 3,40 untuk isi pesan menujukkan visi misi dan 3,47 untuk isi pesan iklan mampu menumbuhkan tanggung jawab moral untuk menggunakan hak pilih. Terkait pertanyaan apakah responden percaya 
pesan iklan politik Gus Ipul Puti versi Dilan dan Milea menarik perhatian (item 11), sebesar $71 \%$ responden

menunjukkan setuju berbanding $10 \%$ yang menyatakan ketidak setujuannya. Dari sisi mean maka komponen pertayaan apakah pesan iklan politik Gus Ipul Puti versi Dilan dan Milea menarik perhatian (item 11) memiliki mean yang paling besar dibandingkan indikator pertanyaan lainnya. Terkait format pesan, responden percaya bahwa audio yang digunakan dalam iklan politik Gus Ipul Puti versi Dilan bisa mendukung penyampaian gagasan tentang kandidat .maka 59 \% responden setuju berbanding $15 \%$ responden yang tidak setuju.(item 20). Dari sisi sumber pesan responden percaya bahwa pemain dalam iklan politik Gus Ipul versi Dilan memiliki kemampuan untuk disukai sebanyak $63 \%$ menujukkan persetujuannya berbanding 10 $\%$.(item23)

Tabel 4 : Kepercayaan Terhadap Isi, Struktur, Format,Sumber Pesan Iklan Gus Ipul -Puti

\begin{tabular}{|c|c|c|c|c|c|c|c|}
\hline \multirow[t]{2}{*}{ Pernyataan } & \multicolumn{5}{|c|}{ Jawaban } & \multirow[t]{2}{*}{ Mean } & \multirow{2}{*}{$\begin{array}{l}\text { Total } \\
\text { Mean }\end{array}$} \\
\hline & STS & TS & $\mathrm{N}$ & $S$ & SS & & \\
\hline \multicolumn{7}{|l|}{ ISI } & \multirow[t]{4}{*}{3,50} \\
\hline Item 8 & 5 & 12 & 25 & 54 & 4 & 3,40 & \\
\hline Item 9 & 1 & 12 & 26 & 46 & 15 & 3,62 & \\
\hline Item 10 & 2 & 11 & 35 & 42 & 10 & 3,47 & \\
\hline \multicolumn{8}{|l|}{ STRUKTUR } \\
\hline Item 1 & 3 & 7 & 19 & 46 & 25 & 3,83 & \multirow[t]{5}{*}{3,46} \\
\hline Item 12 & 2 & 20 & 30 & 41 & 7 & 3,31 & \\
\hline Item 13 & 6 & 14 & 28 & 48 & 4 & 3,30 & \\
\hline Item 14 & 5 & 13 & 33 & 36 & 13 & 3,39 & \\
\hline Item 15 & 3 & 16 & 30 & 33 & 18 & 3,47 & \\
\hline \multicolumn{8}{|l|}{ FORMAT } \\
\hline Item 16 & 3 & 16 & 30 & 39 & 12 & 3,41 & \multirow[t]{5}{*}{3,51} \\
\hline Item 17 & 0 & 10 & 44 & 27 & 9 & 3,45 & \\
\hline Item 18 & 1 & 9 & 34 & 45 & 11 & 3,56 & \\
\hline Item 19 & 0 & 13 & 29 & 49 & 9 & 3,54 & \\
\hline Item 20 & 0 & 15 & 26 & 46 & 13 & 3,57 & \\
\hline \multicolumn{8}{|l|}{$\begin{array}{l}\text { SUMBER } \\
\text { PESAN }\end{array}$} \\
\hline Item 21 & 4 & 9 & 27 & 47 & 13 & 3,56 & \multirow[t]{3}{*}{3,44} \\
\hline Item 22 & 5 & 23 & 38 & 28 & 6 & 3,07 & \\
\hline Item 23 & 3 & 7 & 27 & 44 & 19 & 3,69 & \\
\hline
\end{tabular}

Sumber : Hasil Olahan Peneliti

b.Komponen Nilai Terhadap Iklan Gus Ipul - Puti
Aspek nilai dalam opini menyangkut aspek kesukaan responden terhadap iklan para kandidat. Terkait isi iklan kandidat Gus Ipul-Puti responden menunjukkan aspek kesukaan bahwa iklan politik Gus Ipul - Puti versi Dilan menunjukkan sisi positif pasangan kandidat (item 25) sebesar $70 \%$ yang setuju berbanding $8 \%$ yang tidak setuju. Komponen struktur pesan iklan terdiri dari 5 pertanyaan. Terkait pertanyaan apakah responden menyukai pesan iklan politik Gus Ipul Puti versi Dilan dan Milenah menarik perhatian(Item 27), sebesar $73 \%$ responden menunjukkan setuju berbanding $12 \%$ yang menyatakan ketidaksetujuannya. Dilihat dari sisi mean maka komponen pertayaan apakah pesan iklan politik Gus Ipul Puti versi Dilan dan Milea menarik perhatian memiliki mean yang paling besar dibandingkan indikator pertanyaan lainnya yaitu sebesar 3,75. Dari aspek

kesukaan responden terkait kata kata yang diucapkan dalam iklan politik Gus Ipul Puti versi Dilan adalah benar (item 33) maka responden yang setuju sebesar 59 berbanding $12 \%$ responden yang tidak setuju. Terakhir, apakah responden menyukai bahwa audio yang digunakan dalam iklan politik Gus Ipul Puti versi Dilan bisa mendukung penyampaian gagasan tentang kandidat maka 59 \% responden menunjukkan persetujuannya berbanding $10 \%$ yang tidak setuju. (item 36)Terkait pertanyaan apakah responden menyukai bahwa pemain dalam iklan politik Gus Ipul versi Dilan mampu menyampaikan gagasan tentang kandidat dengan baik (item 37) sebanyak $54 \%$ menujukkan persetujuannya berbanding $20 \%$. Sedangkan untuk indikator apakah responden menyukai pemain dalam iklan politik Gus Ipul versi Dilan memiliki kemampuan untuk disukai (item 39) maka 
$54 \%$ responden menujukkan persetujuannya berbanding $14 \%$ responden yang tidak setuju. Dari ketiga indikator pertanyaan ini maka mean terbesar muncul dari indikator apakah responden menyukai pemain dalam iklan politik Gus Ipul versi Dilan karena memiliki kemampuan untuk disukai dengan mean 3,47 .

Tabel 5 : Nilai Terhadap Isi, Struktur, Format, Sumber,Pesan Iklan Gus Ipul -Puti

\begin{tabular}{|c|c|c|c|c|c|c|c|}
\hline \multirow[t]{2}{*}{ Pernyataan } & \multicolumn{5}{|c|}{ Jawaban } & \multirow[t]{2}{*}{ Mean } & \multirow{2}{*}{$\begin{array}{l}\text { Total } \\
\text { Mean }\end{array}$} \\
\hline & STS & TS & $\mathrm{N}$ & $\mathrm{S}$ & SS & & \\
\hline \multicolumn{8}{|l|}{ ISI } \\
\hline Item 24 & 2 & 14 & 22 & 50 & 12 & 3,56 & \multirow[t]{3}{*}{3,63} \\
\hline Item 25 & 2 & 6 & 22 & 54 & 16 & 3,76 & \\
\hline Item 26 & 2 & 11 & 27 & 49 & 11 & 3,56 & \\
\hline \multicolumn{8}{|l|}{ STRUKTUR } \\
\hline Item 27 & 3 & 9 & 15 & 56 & 17 & 3,75 & \multirow[t]{5}{*}{3,44} \\
\hline Item 28 & 2 & 17 & 32 & 43 & 6 & 3,34 & \\
\hline Item 29 & 2 & 20 & 29 & 44 & 5 & 3,30 & \\
\hline Item 30 & 0 & 18 & 30 & 43 & 9 & 3,43 & \\
\hline Item 31 & 3 & 16 & 31 & 39 & 11 & 3,39 & \\
\hline \multicolumn{8}{|l|}{ FORMAT } \\
\hline Item 32 & 5 & 25 & 27 & 36 & 7 & 3,15 & \multirow[t]{5}{*}{3,48} \\
\hline Item 33 & 1 & 11 & 29 & 53 & 6 & 3,52 & \\
\hline Item 34 & 1 & 7 & 34 & 50 & 8 & 3,57 & \\
\hline Item 35 & 2 & 12 & 29 & 44 & 13 & 3,54 & \\
\hline Item 36 & 2 & 8 & 31 & 46 & 13 & 3,60 & \\
\hline \multicolumn{8}{|l|}{$\begin{array}{l}\text { SUMBER } \\
\text { PESAN }\end{array}$} \\
\hline Item 37 & 6 & 14 & 26 & 47 & 7 & 3,35 & \multirow[t]{3}{*}{3,32} \\
\hline Item 38 & 6 & 17 & 41 & 29 & 7 & 3,14 & \\
\hline Item 39 & 4 & 10 & 32 & 43 & 11 & 3,47 & \\
\hline
\end{tabular}

Sumber : Hasil Olahan Peneliti

\section{c.Komponen Pengharapan Terhadap Iklan Gus Ipul Puti}

Dalam aspek pengharapan responden terhadap iklan para kandidat kandidat bisa dicermati dari sebaran tabel di atas. Kategori isi iklan politik mampu mendorong rasa tanggung jawab moral menggunakan hak pilih (item 42) sebanyak $78 \%$ setuju berbanding $6 \%$ yang tidak setuju. Dilihat dari segi mean terbesar maka komponen harapan terkait isi pesan mampu menumbuhkan sisi positif pasangan kandidat memperoleh mean yang paling besar sebesar 3,98 (item41) berbanding 3,81 untuk isi pesan menujukkan visi misi dan untuk 3,90 untuk isi pesan iklan mampu menumbuhkan tanggung jawab moral untuk menggunakan hak pilih. Terkait pertanyaan apakah responden berharap pesan iklan politik Gus Ipul Puti versi Dilan dan Milenah menarik perhatian(Item 43), sebesar $78 \%$ responden menunjukkan setuju berbanding $10 \%$ yang menyatakan ketidaksetujuannya. Dilihat dari sisi mean maka komponen pertayaan kmemiliki mean yang paling besar dibandingkan indikator pertanyaan lainnya yaitu sebesar 3,97(item 43)

Dilihat dari apakah responden berharap bahwa video yang digunakan dalam iklan politik Gus Ipul Puti versi Dilan bisa menyampaikan gagasan tentang kandidat (item 51) maka $74 \%$ responden setuju berbanding $6 \%$ responden yang tidak setuju. Jika dilihat dari perbandingan mean maka komponen video menunjukkan mean terbesar berbading komponen audio, judul, kata kata, dan warna terkait format pesan dalam iklan politik Gus Ipul Versi Dilan yaitu sebesar 3,90.

Terkait pertanyaan apakah responden berharap pemain dalam iklan politik Gus Ipul versi Dilan mampu menyampaikan gagasan tentang kandidat dengan baik (item 53) sebanyak $75 \%$ menunjukkan persetujuannya berbanding $7 \%$. Dari ketiga indikator pertanyaan ini maka mean terbesar muncul dari indikator apakah responden berharap bahwa pemain dalam iklan politik Gus Ipul versi Dilan mampu menyampaikan gagasan tentang kandidat dengan baik yaitu sebesar 3,92 (item 53)

Tabel 6 : Komponen Pengharapan Terhadap Isi , Struktur, Format, Sumber Pesan Iklan Gus Ipul - Puti

\begin{tabular}{|c|c|c|c|c|c|c|c|}
\hline \multirow[t]{2}{*}{ Pernyataan } & \multicolumn{5}{|c|}{ Jawaban } & \multirow[t]{2}{*}{ Mean } & \multirow{2}{*}{$\begin{array}{l}\text { Total } \\
\text { Mean }\end{array}$} \\
\hline & STS & TS & $\mathrm{N}$ & $\mathrm{S}$ & SS & & \\
\hline \multicolumn{8}{|l|}{ ISI } \\
\hline Item 40 & 1 & 11 & 12 & 58 & 18 & 3,81 & \multirow[t]{3}{*}{3,90} \\
\hline Item 41 & 0 & 3 & 17 & 59 & 21 & 3,98 & \\
\hline Item 42 & 1 & 5 & 16 & 59 & 19 & 3,90 & \\
\hline \multicolumn{8}{|l|}{ STRUKTUR } \\
\hline Item 43 & 1 & 9 & 12 & 48 & 30 & 3,97 & \multirow[t]{5}{*}{3,82} \\
\hline Item 44 & 1 & 10 & 20 & 56 & 13 & 3,70 & \\
\hline Item 45 & 0 & 7 & 18 & 57 & 18 & 3,86 & \\
\hline Item 46 & 0 & 6 & 19 & 52 & 23 & 3,92 & \\
\hline Item 47 & 0 & 9 & 33 & 42 & 16 & 3,65 & \\
\hline
\end{tabular}




\begin{tabular}{|c|c|c|c|c|c|c|c|}
\hline FORMAT & & & & & & & \\
\hline Item 48 & 5 & 25 & 30 & 30 & 10 & 3,15 & \multirow[t]{5}{*}{3,65} \\
\hline Item 49 & 1 & 9 & 28 & 43 & 19 & 3,70 & \\
\hline Item 50 & 1 & 6 & 31 & 49 & 13 & 3,67 & \\
\hline Item 51 & 0 & 6 & 20 & 52 & 22 & 3,90 & \\
\hline Item 52 & 0 & 6 & 24 & 50 & 20 & 3,84 & \\
\hline \multicolumn{8}{|l|}{$\begin{array}{l}\text { SUMBER } \\
\text { PESAN }\end{array}$} \\
\hline Item 53 & 1 & 6 & 18 & 50 & 25 & 3,92 & \multirow[t]{3}{*}{3,85} \\
\hline Item 54 & 2 & 5 & 24 & 48 & 21 & 3,81 & \\
\hline Item 55 & 2 & 6 & 18 & 57 & 17 & 3,81 & \\
\hline
\end{tabular}

Sumber : Hasil Olahan Penulis

\section{d. Komponen Kepercayaan Terhadap} Iklan Khofifah -Emil.

Opini responden terhadap iklan Khofifah - Emil juga dilihat dari komponen kepercayaan, nilai, dan pengharapan terhadap isi, struktur, format dan sumber pesan iklan. Terkait komponen kepercayaan dalam kategori isi pesan menunjukkan visi misi pasangan calon (item 56) tingkat kepercayaan responden sebesar $71 \%$ setuju berbanding $8 \%$ yang tidak setuju. Dilihat dari segi mean terbesar maka responden percaya isi pesan mampu menujukkan visi misi memperoleh mean yang paling besar sebesar 3,88 (item 56) berbanding 3,76 untuk isi pesan menumbuhkan sisi positif pasangan kandidat dan 3,44 untuk isi pesan iklan mampu menumbuhkan tanggung jawab moral untuk menggunakan hak pilih.

Terkait struktur pesan iklan apakah responden percaya bahwa visualisasi di iklan politik Khofifah Emil versi Nawa Bhakti Satya (item 62) memberi gambaran yang jelas terkait gagasan tentang calon kandidat, $60 \%$ responden menunjukkan kesetujuannya berbanding $18 \%$ yang tidak setuju. Dilihat dari sisi mean maka komponen pertayaan apakah pesan iklan politik Khofifah Emil versi Nawa Bhakti Satya mampu memenuhi kebutuhan anda tentang figur calon mean yang paling besar dibandingkan indikator pertanyaan lainnya yaitu sebesar 3,52.(item 60). Terkait kepercayaan terhadap judul iklan politik Khofifah Emil versi Nawa Bhakti Satya (item 64 ) maka $63 \%$ responden menujukkan setuju berbanding $11 \%$ yang tidak setuju.

Jika dilihat dari perbandingan mean terkait format pesan dalam iklan politik Khofifah Emil versi Nawa Bhakti Satya maka komponen judul menunjukkan mean terbesar berbading komponen warna, audio, kata kata dan video. Responden percaya bahwa pemain dalam iklan politik Khofifah Emil versi Nawa Bhakti Satya mampu menyampaikan gagasan tentang kandidat dengan baik (item 69) sebanyak $63 \%$ menujukkan persetujuannya berbanding $12 \%$. Dari ketiga indikator pertanyaan ini maka mean terbesar muncul dari indikator apakah responden percaya bahwa pemain dalam iklan politik Khofifah Emil versi Nawa Bhakti Satya mampu menyampaikan gagasan tentang kandidat dengan baik sebesar 3,61 (item 69).

Tabel 7 :Kepercayaan Terhadap Isi, Struktur, Format, Sumber Pesan Iklan Iklan Khofifah Emil

\begin{tabular}{|c|c|c|c|c|c|c|c|}
\hline \multirow[t]{2}{*}{ Pernyataan } & \multicolumn{5}{|c|}{ Jawaban } & \multirow[t]{2}{*}{ Mean } & \multirow{2}{*}{$\begin{array}{l}\text { Total } \\
\text { Mean }\end{array}$} \\
\hline & STS & TS & $\mathrm{N}$ & $S$ & SS & & \\
\hline \multicolumn{8}{|l|}{ ISI } \\
\hline Item 56 & 2 & 6 & 21 & 44 & 27 & 3,88 & \multirow[t]{3}{*}{3,69} \\
\hline Item 57 & 1 & 10 & 20 & 50 & 19 & 3,76 & \\
\hline Item 58 & 1 & 16 & 30 & 44 & 9 & 3,44 & \\
\hline \multicolumn{8}{|l|}{ STRUKTUR } \\
\hline Item 59 & 5 & 20 & 31 & 35 & 9 & 3,23 & \multirow[t]{5}{*}{3,37} \\
\hline Item 60 & 3 & 10 & 28 & 50 & 9 & 3,52 & \\
\hline Item 61 & 3 & 14 & 27 & 48 & 8 & 3,44 & \\
\hline Item 62 & 3 & 15 & 22 & 48 & 12 & 3,51 & \\
\hline Item 63 & 4 & 20 & 36 & 37 & 3 & 3,15 & \\
\hline \multicolumn{8}{|l|}{ FORMAT } \\
\hline Item 64 & 2 & 9 & 26 & 46 & 17 & 3,67 & \multirow[t]{5}{*}{3,57} \\
\hline Item 65 & 2 & 13 & 38 & 39 & 8 & 3,38 & \\
\hline Item 66 & 1 & 6 & 39 & 45 & 9 & 3,55 & \\
\hline Item 67 & 2 & 7 & 28 & 51 & 12 & 3,64 & \\
\hline Item 68 & 2 & 11 & 29 & 42 & 16 & 3,59 & \\
\hline \multicolumn{8}{|l|}{$\begin{array}{l}\text { SUMBER } \\
\text { PESAN }\end{array}$} \\
\hline Item 69 & 2 & 10 & 25 & 51 & 12 & 3,61 & \multirow[t]{3}{*}{3,54} \\
\hline Item 70 & 1 & 9 & 30 & 50 & 10 & 3,59 & \\
\hline Item 71 & 2 & 13 & 33 & 45 & 7 & 3,42 & \\
\hline
\end{tabular}

Sumber : Hasil Olahan Peneliti

\section{e. Komponen Nilai Terhadap Iklan Khofifah-Emil.}

Dalam komponen nilai terhadap iklan politik Khofifah Emil, responden juga menunjukkan persetujuan sebesar $67 \%$ berbanding $12 \%$ yang tidak setuju terkait aspek kesukaan bahwa iklan politik 


\section{Sumber : Hasil Olahan Peneliti}

Khofifah Emil versi Nawa Bhakti Satya menunjukkan sisi positif pasangan kandidat (item 73). Dilihat dari segi mean maka isi pesan mampu menumbuhkan sisi positif pasangan kandidat memperoleh mean yang paling besar sebesar 3,67 (item 73) berbanding 3,48 untuk isi pesan menujukkan visi misi dan 3,50 untuk isi pesan iklan mampu menumbuhkan tanggung jawab moral untuk menggunakan hak pilih.

Dari segi struktur pesan responden yang menyukai iklan politik tersebut mampu memenuhi kebutuhan anda tentang figur calon (item 76) sebesar $52 \%$ menunjukkan persetujuannya berbanding dengan $17 \%$ yang tidaksetuju dan $31 \%$ berada pada posisi Netral. Dilihat dari sisi mean maka komponen pertayaan apakah pesan iklan politik Khofifah Emil versi Nawa Bhakti Satya mampu memenuhi kebutuhan anda tentang figur calon memperoleh mean yang paling besar dibandingkan indikator pertanyaan lainnya yaitu sebesar 3,42 (item 76)

Terkait aspek format apakah responden menyukai video yang digunakan dalam iklan politik Khofifah Emil versi Nawa Bhakti Satya bisa menyampaikan gagasan tentang kandidat (item 83) maka $55 \%$ responden setuju berbanding $15 \%$ responden yang tidak setuju. Jika dilihat dari perbandingan mean maka komponen judul menunjukkan mean terbesar berbading komponen audio, warna, kata kata, dan video terkait format pesan dalam iklan politik Khofifah Emil versi Nawa Bhakti Satya yaitu sebesar 3,46 (item 80)

Terkait sumber pesan apakah responden menyukai bahwa pemain dalam iklan politik Khofifah Emil versi Nawa Bhakti Satya mampu menyampaikan gagasan tentang kandidat dengan baik (item 85) sebanyak $58 \%$ menujukkan persetujuannya berbanding $17 \%$. Dari ketiga indikator pertanyaan ini maka mean terbesar muncul dari indikator apakah responden menyukai bahwa pemain dalam iklan politik Khofifah Emil versi Nawa Bhakti Satya mampu menyampaikan gagasan tentang kandidat dengan baik yaitu sebesar 3,48

Tabel 8: Komponen Nilai Terhadap Terhadap Isi , Struktur, Format,Sumber Pesan Iklan Khofifah - Emil

\begin{tabular}{|c|c|c|c|c|c|c|c|}
\hline \multirow[t]{2}{*}{ Pernyataan } & \multicolumn{5}{|c|}{ Jawaban } & \multirow[t]{2}{*}{ Mean } & \multirow{2}{*}{$\begin{array}{l}\text { Total } \\
\text { Mean }\end{array}$} \\
\hline & STS & TS & $\mathrm{N}$ & $\mathrm{S}$ & SS & & \\
\hline \multicolumn{8}{|l|}{ ISI } \\
\hline Item 72 & 1 & 16 & 27 & 46 & 10 & 3,48 & \multirow[t]{3}{*}{3,55} \\
\hline Item 73 & 1 & 11 & 21 & 54 & 13 & 3,67 & \\
\hline Item 74 & 1 & 12 & 32 & 46 & 9 & 3,50 & \\
\hline \multicolumn{8}{|l|}{ STRUKTUR } \\
\hline Item 75 & 5 & 19 & 33 & 37 & 6 & 3,20 & \multirow[t]{5}{*}{3,32} \\
\hline Item 76 & 1 & 16 & 31 & 44 & 8 & 3,42 & \\
\hline Item 77 & 1 & 19 & 31 & 43 & 6 & 3,34 & \\
\hline Item 78 & 2 & 19 & 30 & 44 & 5 & 3,31 & \\
\hline Item 79 & 2 & 16 & 40 & 33 & 9 & 3,31 & \\
\hline \multicolumn{8}{|l|}{ FORMAT } \\
\hline Item 80 & 2 & 16 & 29 & 40 & 13 & 3,46 & \multirow[t]{5}{*}{3,40} \\
\hline Item 81 & 2 & 16 & 29 & 44 & 9 & 3,42 & \\
\hline Item 82 & 4 & 16 & 34 & 40 & 6 & 3,28 & \\
\hline Item 83 & 3 & 12 & 30 & 48 & 7 & 3,44 & \\
\hline Item 84 & 2 & 16 & 33 & 40 & 9 & 3,38 & \\
\hline \multicolumn{8}{|l|}{$\begin{array}{l}\text { SUMBER } \\
\text { PESAN }\end{array}$} \\
\hline Item 85 & 3 & 14 & 25 & 48 & 10 & 3,48 & \multirow[t]{3}{*}{3,42} \\
\hline Item 86 & 2 & 14 & 33 & 45 & 6 & 3,39 & \\
\hline Item 87 & 1 & 12 & 42 & 37 & 8 & 3,39 & \\
\hline
\end{tabular}

Sumber : Hasil Olahan Peneliti

\section{f.Komponen Pengharapan Terhadap Iklan Khofifah-Emil.}

Aspek harapan responden merupakan salah satu komponen dari opini . Terkait aspek isi pesan responden menunjukkan persetujuan harapan bahwa iklan politik Khofifah Emil versi Nawa Bhakti Satya menunjukkan sisi positif pasangan kandidat (item 89) sebesar $72 \%$ berbanding $7 \%$ yang tidak setuju. Dilihat dari segi mean maka komponen harapan tentang isi pesan mampu menumbuhkan sisi positif pasangan kandidat memperoleh mean yang paling besar sebesar 3,81 berbanding 3,77 untuk isi pesan menujukkan visi misi dan 3,69 untuk isi pesan iklan mampu menumbuhkan tanggung jawab moral untuk menggunakan hak pilih. 
Dilihat dari indikator pertanyaan apakah responden berharap iklan politik Khofifah Emil versi Nawa Bhakti Satya memberi kepuasan anda terkait gagasan tentang calon kandidat (item 93) maka 66 $\%$ responden setuju berbanding $13 \%$ yang tidak setuju. Terkait struktur pesan iklan apakah responden berharap visualisasi di iklan politik Gus Ipul Puti versi Dilan memberi gambaran yang jelas terkait gagasan tentang calon kandidat (item 94), $66 \%$ responden menunjukkan persetujuannya berbanding $9 \%$ yang tidak setuju. Dilihat dari sisi mean maka komponen pertayaan apakah responden berharap pesan iklan politik Khofifah Emil versi Nawa Bhakti Satya mampu memenuhi kebutuhan anda tentang figur calon dibandingkan indikator pertanyaan lainnya yaitu sebesar 3,70 (item 92)

Dilihat dari apakah responden berharap bahwa video yang digunakan dalam iklan politik Khofifah Emil berjudul Nawa Bhakti Satya bisa menyampaikan gagasan tentang kandidat (item 99) maka $67 \%$ responden setuju berbanding $13 \%$ responden yang tidak setuju. Jika dilihat dari perbandingan mean maka komponen video menunjukkan mean terbesar berbanding komponen audio, judul, kata kata, dan warna terkait format pesan dalam iklan politik Khofifah Emil berjudul Nawa Bhakti Satya yaitu sebesar 3,69. (Item 99)

Terkait pertanyaan apakah responden berharap pemain dalam iklan politik Khofifah Emil berjudul Nawa Bhakti Satya mampu menyampaikan gagasan tentang kandidat dengan baik (item 101) sebanyak $71 \%$ menujukkan persetujuannya berbanding $9 \%$. Dari ketiga indikator pertanyaan ini maka mean terbesar muncul dari indikator apakah responden berharap bahwa pemain dalam iklan politik Khofifah Emil berjudul Nawa Bhakti Satya mampu menyampaikan gagasan tentang kandidat dengan baik yaitu sebesar 3,78 (item 101)
Tabel 9 : Pengharapan Terhadap Isi , Struktur, Format, Sumber Pesan Iklan Khofifah - Emil

\begin{tabular}{|c|c|c|c|c|c|c|c|}
\hline \multirow[t]{2}{*}{ Pernyataan } & \multicolumn{5}{|c|}{ Jawaban } & \multirow[t]{2}{*}{ Mean } & \multirow{2}{*}{$\begin{array}{l}\text { Total } \\
\text { Mean }\end{array}$} \\
\hline & STS & TS & $\mathrm{N}$ & $\mathrm{S}$ & SS & & \\
\hline \multicolumn{8}{|l|}{ ISI } \\
\hline Item 88 & 0 & 8 & 24 & 51 & 17 & 3,77 & \multirow[t]{3}{*}{3,76} \\
\hline Item 89 & 1 & 6 & 21 & 55 & 17 & 3,81 & \\
\hline Item 90 & 0 & 9 & 29 & 46 & 16 & 3,69 & \\
\hline \multicolumn{8}{|l|}{ STRUKTUR } \\
\hline Item 91 & 3 & 13 & 23 & 49 & 12 & 3,54 & \multirow[t]{5}{*}{3,59} \\
\hline Item 92 & 1 & 7 & 25 & 51 & 14 & 3,70 & \\
\hline Item 93 & 1 & 12 & 21 & 56 & 10 & 3,62 & \\
\hline Item 94 & 2 & 7 & 25 & 55 & 11 & 3,66 & \\
\hline Item 95 & 2 & 14 & 31 & 43 & 10 & 3,45 & \\
\hline \multicolumn{8}{|l|}{ FORMAT } \\
\hline Item 96 & 2 & 16 & 35 & 35 & 12 & 3,39 & \multirow[t]{5}{*}{3,57} \\
\hline Item 97 & 1 & 11 & 28 & 42 & 18 & 3,65 & \\
\hline Item 98 & 1 & 10 & 38 & 36 & 15 & 3,54 & \\
\hline Item 99 & 1 & 12 & 20 & 51 & 16 & 3,69 & \\
\hline Item 100 & 1 & 11 & 31 & 44 & 13 & 3,57 & \\
\hline \multicolumn{8}{|l|}{$\begin{array}{l}\text { SUMBER } \\
\text { PESAN }\end{array}$} \\
\hline Item 101 & 1 & 8 & 20 & 54 & 17 & 3,78 & \multirow[t]{3}{*}{3,72} \\
\hline Item 102 & 0 & 6 & 25 & 57 & 12 & 3,75 & \\
\hline Item 103 & 0 & 7 & 32 & 52 & 9 & 3,63 & \\
\hline
\end{tabular}

Sumber : Hasil Olahan Peneliti

Untuk iklan Gus Ipul Puti persebaran opini pemilih pemula terhadap iklan versi Milea bisa dilihat dalam tabel di bawah ini:

Tabel 10 : Persebaran komponen opini pemilih pemula terhadap iklan Gus Ipul -Puti

\begin{tabular}{|l|c|l|l|}
\hline \multirow{2}{*}{ Kategori } & Kepercayaan & Nilai & Harapan \\
\cline { 2 - 4 } & $\%$ & $\%$ & $\%$ \\
\hline Rendah & 21 & 20 & 9 \\
\hline Tinggi & 79 & 80 & 91 \\
\hline
\end{tabular}

Sumber : Hasil Olahan Peneliti

Sedangkan untuk iklan Khofifah - Emil versi Nawa Bhakti Satya maka persebaran opini pemilih pemula terhadap iklan tersebut dapat dilihat sebagai berikut :

Tabel 11 : Persebaran komponen opini pemilih pemula terhadap iklan Khofifah-Emil

\begin{tabular}{|l|c|l|l|}
\hline Kategori & Kepercayaan & Nilai & Harapan \\
\cline { 2 - 4 } Komponen & $\%$ & $\%$ & $\%$ \\
\hline Rendah & 23 & 28 & 21 \\
\hline Tinggi & 77 & 72 & 79 \\
\hline
\end{tabular}

Sumber : Hasil Olahan Peneliti 
Untuk opini pemilih pemula terhadap iklan masing masing kandidat dapat dilihat dari tabel di bawah ini :

Tabel 12 : opini pemilih pemula terhadap iklan pasangan kandidat

\begin{tabular}{|l|c|l|}
\hline \multirow{2}{*}{ Kategori } & Gus Ipul-Puti & $\begin{array}{l}\text { Khofifah } \\
\text { Emil }\end{array}$ \\
\cline { 2 - 3 } & $\%$ & $\%$ \\
\hline Rendah & 14 & 20 \\
\hline Tinggi & 86 & 80 \\
\hline
\end{tabular}

Sumber : Hasil Olahan Peneliti

Secara umum opini pemilih pemula di Surabaya tentang iklan Politik Kandidat Pilgub Jatim baik pasangan Khofifah-Emil maupun Gus Ipul Puti menghasilkan opini yang positif atau tinggi. Hal ini tentu saja dikarenakan komponen opini kedua iklan baik dari iklan Gus Ipul - Puti versi Dilan maupun iklan Khofifah-Emil versi Nawa Bhakti Satya yang terdiri dari kepercayaan, Nilai, dan pengharapan pemilih pemula terhadap iklan tersebut juga positif atau tinggi. Artinya pemilih pemula Surabaya percaya bahwa iklan Gus Ipul maupun Khofifah mampu dan bisa digunakan sebagai medium untuk memperkenalkan figur calon terutama visi misi. Selain itu dari segi nilai yaitu antara suka maupun tidak menyukai maka 70 \% lebh pemilih pemula Surabaya menyukai kedua iklan politik masing masing kandidat. Meskipun dari segi konten iklan kedua pasangan memiliki titik poin yang berbeda. Jika iklan Gus Ipul dibuat dengan versi cerita sedangkan iklan politik Khofifah dibuat dalam bentuk informasi poin poin visi misi. Sedangkan poin terakhir terkait pengharapan, pemilih pemula Surabaya memiliki harapan yang besar baik harapan terhadap iklan Gus Ipul di angka $91 \%$ dan Khofifah di angka 79 \%. Hal ini menunjukkan sebagai pemilih pemula sangat berharap bahwa iklan politik ini khususnya melalui social media menjadi saluran yang bisa memberikan informasi bagi mereka untuk mendapatkan informasi terkait kandidat, visi misi, sekaligus memperteguh pilihan mereka.
Opini merupakan ekspresi dari sikap atas sebuah isu. Ketika ada sebuah isu maka kita akan punya kecendrungan untuk bersikap dan ketika kita mengekspresikan sikap tersebut maka hal tersebut menjadi opini. Dalam konteks kemunculan iklan politik yang bertujuan mempengaruhi sikap, keyakinan atau bahkan perilaku sasarannya maka menjadi penting untuk menampilkan kesan yang positif melalui elemen elemen iklan tersebut.

Pemilih pemula merupakan kelompok yang unik sebagai sasaran kampanye. Dalam beberapa artikel disebutkan karakteritik pemilih pemula antara lain semangat voluntarisme yang menjadi pendorong mau bergabung dalam aksi aksi relawan dibanding partai politik dan lebih mengedepankan solidaritas berbasi isu meski ada juga yang masih memuja figure; sifat kolegialitas yang berangkat dari semangat untuk eksis dan menunjukkan representasi diri dengan membentuk kelompok sendiri sehingga kelompok ini sendiri menjadi sasaran yang potensial untuk "digarap" termasuk dalam urusan politis serta identik dengan sikap apolitis dan apatis. (meskipun pada perkembangannya tingkat partisipasi politik pemilih pemula dalam beberapa kali pilpres terakhir cukup tinggi). Sebuah sikap yang tampaknya merupakan peranan dari aspek keluarga. (Wasisto Raharjo Jati, 2019). Pada akhirnya, karakteristik pemilih pemula yang punya kecendrungan belum memutuskan dalam urusan memilih menempatkan kelompok ini pada kelompok swing voters.

Terkait komponen opini yang terdiri dari kepercayaan, nilai dan pengharapan maka berdasarkan temuan dalam iklan Gus Ipul Puti ada tren positif yang bergerak progresif/naik dari kepercayaan lalu ke aspek nilai dan harapannya. Sedangkan untuk iklan Khofifah-Emil meski dalam tone yang positif namun gerakan tren psotif tersebut sempat turun dari aspek kepercayaan ke

Analisa 
nilai lalu naik kembali ke aspek kepercayaan.

\section{Kesimpulan}

Opini publik merupakan satu bentuk manifestasi dari praktek demokrasi bagi warga negara. Dalam hal ini masyarakat yang beropini merupakan bentuk berjalannya sebuah praktek kemerdekaan berpendapat. Lebih jauh dalam konteks pemilihan umum, opini publik bisa dijadikan patokan bagi para kandidat untuk mengukur sejauh mana publik mengenal, mempercayai mereka, isu-isu yang mereka bahas dan solusi yang para kandidat tawarkan sekaligus apakah para pemilih akan memberikan hak suaranya kepada kandidat tersebut.

Dalam praktek pemilihan umum, mengkomunikasikan para kandidat baik dari segi profil, isu, visi misi bisa dilakukan dengan berbagai macam cara dan saluran. Salah satunya iklan politik. Termasuk dalam Pilgub Jatim 2018 ini kedua kandidat mengeluarkan beragam iklan politik baik melalui media cetak televisi termasuk social media.

\section{Referensi}

Azwar, S. 2008. Sikap manusia: Teori dan pengukurannya (ed.4). Yogyakarta: Pustaka Pelajar.

Cangara, Hafied. 2011. Komunikasi Politik. Konsep, Teori dan Strategi. Rajawali Pers: Jakarta.

Dan Nimmo, 1989. Komunikasi Politik: Komunikator, pesan dan media, Remaja Rosda Karya: Bandung

Ochtiva, Belinda. 2017. Opini Pemilih Pemula Surabaya Terhadap Citra yang Ditampilkan Pada Iklan Politik Mars Perindo. Skripsi : Universitas Airlangga.

Heryanto Gun Gun dan Rumaru, Shulhan. Komunikasi Politik: Sebuah Pengantar. Bogor: Penerbit Ghalia Indonesia, 2013.
Jalil, Abdul. 2011. Analisis Opini Pemilih Pemula Terhadap Iklan Politik Dalam Pemilihan Walikota Makassar Tahun 2008. Jurnal Kareba : Vol 1 No.13 hal 297-312.

Kaid, Lynda Lee. 2015. Handbook Penelitian Komunikasi Politik. (ed.terjemahan). Penerbit Nusa Media : Bandung.

Kotler, Philip.2003. Manajemen Pemasaran. Edisi kesebelas, Jakarta: Indeks kelompok Gramedia

Milton, Rokeach. 1968. Belief, attitudes, and Values, Jossey- Bass, San Fransisco.

Pawito, 2009, Komunikasi Politik: Media Massa Dan Kampanye Pemilihan, Edisi Pertama, Jalasutra, Yogyakarta.

Santosa, PB \& Ashari. 2005. Analisis Statistik dengan Microsoft Excel \& SPSS. ANDI Yogyakarta : Yogyakarta

Sulistyo Ervina.2014. Opini Pemilih Pemula mengenai Iklan Politik kuis Kebangsaan Win HT Partai Hanura di RCTI. Skripsi : Universitas Kristen Petra.

Wells, Burnett, Moriarty. Advertising. Principles and Practice. 1989. Prentice Hall,Inc : New Jersey.

Artikel Online :

http://nasional.kompas.com/read/20 18/01/11/19120451/fakta-seputarpilkada-jawa-timur) Pemilih pemula dalam Pilpres 2019, bagaimana karakter mereka di tengah menguatnya konservatisme (2019, April 16) . diakses 10 desember 2020 dari artikel

https://theconversation.com/pemilihpemula-dalam-pilpres-2019-bagaimanakarakter-mereka-di-tengah-menguatnyakonservatisme-114624 